Прегледни чланак

Marija R. Vuković, Ph. D., Professional Studies Professor

Novi Sad School of Business

vlahmari@uns.ac.rs

\title{
ECONOMIC, POLITICAL AND INSTITUTIONAL DETERMINANTS OF FISCAL DEFICIT
}

\begin{abstract}
This paper seeks basic economic and political causes of instability and rising fiscal deficit. Economic factors that may cause the appearance and increase in the fiscal deficit are: growth of current public spending, launching public investments, tax cuts and weakening financial discipline. The government's policy that is a result of its coalition agreement, everywhere in the world, is the primary factor that causes the formation and growth of the fiscal deficit. The aim is to show that the politically unstable countries with weak institutions are often vulnerable to fiscal shocks, which, in turn, lead to the greater instability in the fiscal deficit.
\end{abstract}

Keywords: tax cuts; fiscal illusion; intergenerational redistribution of the burden of public debt; spatial separation of interests; budgetary institutions.

\section{INTRODUCTION}

Lawyers and economists in general recognize that the high and volatile fiscal deficits are harmful to the well-being of the national economy. The reasons for disrupting the balance of the national economy are as follows: first, the fiscal deficit leads to an inefficient allocation of resources and creates problems to the private sector generating the crowding-out effect of investments; second, by increasing the share of debt to gross domestic product (GDP) the fiscal deficit has a negative impact on long-term fiscal sustainability of the country and affects the living standards of future generations; third, the fiscal deficit increases the level of monetary fluctuations and causes instability of the economy, especially when the central bank is not independent enough.

The problem of the fiscal deficit requires an economic analysis which should explain the existence of big differences between the fiscal deficit and public debt 
in the group of relatively homogeneous economies. The task of economics is to detect the causes of the increase in the fiscal deficit and help in finding a solution that would have this problem repaired.

The level of fiscal deficit and public debt significantly vary among the EU countries although specific economic characteristics of these countries are relatively similar. They refer to the form of government (all these countries are developed industrial democracies) and the extent of economic development (measured by the level of income per capita which is very high). Therefore, specific economic conditions of the countries are not enough to explain the large differences in the ratio of debt to gross domestic product (GDP) in them. Therefore, this diversity requires an analysis of the political and institutional factors as the key to understanding the fiscal deficit and fiscal policy itself. Political institutional factors refer to the Law on electoral system, coalition structure of the government, Law on the Budget, Law on the Central Bank, level of fiscal decentralization, etc. These factors vary from country to country.

In this paper, we aim to prove the hypothesis that political and institutional variables more significantly determine the rise in the fiscal deficit than economic variables.

The research starts with the description of the specification of the model, comprising all the key-institutional political factors affecting the fiscal deficit. These factors include variables that measure political conditions, institutions and level of economic stabilization of the country. The models describing the determination by the fiscal deficit will be tested using the methods of Ricardian, neoclassical or institutional economy.

\section{THE ECONOMIC DETERMINANTS OF FISCAL DEFICIT}

Taxation basically results in distortion of economic activity. If the increase of public spending was financed by taxes, the tax rate should be high. High tax rates can cause significant economic distortions ${ }^{1}$ which increase more than in proportion to the amount of increase in tax revenues. The level of distortions created by taxes is proportional to the square of the tax rate, which means that higher tax rates create greater distortions. ${ }^{2}$ Instead of increasing or decreasing the tax rate in order to remain within budgetary constraints, it is better (in terms of

\footnotetext{
${ }^{1}$ High tax rates can be discouraging on people who reduce their productivity or are engaged in illegal activities which are not taxed (tax evasion).

${ }^{2}$ G. Krstić, F. Schneider, M. Arandarenko, M. Arsić, B. Radulović, S. Ranđelović, I. Janković, „Siva ekonomija u Srbiji - novi nalazi i preporuke za reforme“, Fond za razvoj ekonomske nauke, Beograd 2013,113.
} 
reducing distortions) to maintain a constant tax rate over time by tax smoothing. ${ }^{3}$ If there is the negative effect of taxes, distortionary taxation causes excess tax burden, while it is difficult to collect revenue due to the presence of resistance to taxation. Fiscal balance is distorted, because of changes in the tax system, which also changes the size of the tax burden imposed in different years. An optimal tax policy should be to reduce the level of tax burden caused by the present and future taxes within the intertemporal budget constraint. ${ }^{4}$

If public spending is unchanged, the tax cuts must sooner or later be compensated by increase in taxes in the future. A decrease in current tax rates reduces the current tax burden, but this increases the tax burden in the future. The longer the government delays tax increase, the higher increase will be. In this way, the deficit can change the size of the overall tax burden of the tax system. ${ }^{5}$

Government borrowing to finance deficit creates instability in the financial markets. The growth of public debt produced by rising interest rates in the financial market causes a decrease in the volume of investment, or a reduction in the level of economic activity of the country. From the point of view of macroeconomic balance, there is the question of who will bear the burden of deficits and public debt. One possible answer is: (a) the debt burden borne by future generations; (B) the debt burden borne by present and future generations.

The economic determinants of fiscal deficit are an interpretation of the model tax reduction (tax smooting), whose creator is Barro (1979). ${ }^{6}$ This model analyzes the government's efforts to minimize the distortions during the tax collection. The model is based on the theory of Ricardian equivalence. According to the theory of Ricardian equivalence, in the case of the limited budget, borrowing does not change the consumption of any generation; financing through taxation or borrowing are essentially identical. Deficit and debt do not have impact on the economic activity so the fiscal policy is irrelevant. After Ricardian equivalence, the higher deficit is compensated by the increase in private savings in the same

3 Tax smoothing means that the state will have high deficits when government spending is very high and small surpluses in the rest period. See more: Olivier Blanshard, Makroekonomija, Mate, Zagreb 2005, 567.

${ }^{4}$ Intertemporal budget means interim spending of items from the budget. The state can spend its budgetary revenues immediately, or to keep it for the future.

${ }^{5}$ The reason for the reduction of taxes can be a reduction in the overall tax burden which can be explained by the already mentioned square rule. According to this rule, the size of the tax burden grows as the square of the tax rate. If the tax rate is lower at present than in the future, the surplus can reduce the total surplus of the tax burden. Decrease in future tax rates is possible if the surplus reduces the tax burden in the future to a greater extent. Of course, the lost revenue must be offset by higher tax rates in the present, or to the square rule, increasing the burden is less than the fall of the tax burden in the future. See more: Neil Bruce, Public Finance and American Economy, Addison Wesley, New York 2001, 506.

${ }^{6}$ Robert Barro, "On the Determination of the Public Debt", Journal of Political Economy, Vol.87/1979, Issue 5, Part 1, 940-971. 
amount.? The model of "tax smoothing" implies closed economy without capital where one political party advocates consumption and other savings. The government is defined as a "benevolent social planner". According to this model, the government should fund a certain amount of public spending in each period through the income tax, which is discretionary in character (it affects the labour supply). It is advisable that the government keep the tax rate at a constant level. In other words, during economic recession the deficit should be compensated by the surplus due to the economic expansion. ${ }^{8}$ The tax rate is determined by intertemporal budget constraint, which means that the present value of public spending (which is exogenous) must be equal to the present value of the tax. Therefore, the fiscal deficit and surplus are used as a buffer. The deficit occurs when the public spending is high, while a temporary surplus occurs when the public spending is low. ${ }^{9}$

The principle of equalization tax is quite clear: the fiscal deficit and the surpluses are used optimally to minimize the adverse effects of taxation, with some movement of public spending. The significant expansion of the model refers to the cyclical fluctuations of tax revenues due to the business cycle. The model of tax smooting means that tax rates should be constant over the business cycle; therefore, it is necessary to replace deficits during the recession surpluses during expansions.

The basic analysis of the model "tax smoothing" can be extended in three ways. ${ }^{10}$

First, the government can maintain a constant level of tax rates, and increased public spending financed by borrowing. Expected disorders are smaller if the public debt at a low level occurs when there is a positive shock in public spending; the disorders are bigger when there is a negative shock in public spending. With the high level of borrowing, the government can keep the tax rate at a constant level. The strong implication is obviously incorrect. The government may issue the bonds (nominal debt) and then to follow a policy to the amount of high inflation, in response to a positive shock public consumption, and low inflation in response to a negative shock. In this way, the desire to reduce distortion justifies the issuance of the nominal debt.

Second, the analysis can be extended to the accumulation of capital. In the phase of borrowing, the government increased its financial potential, which represents a new foundation for growth of production, employment, investment and

${ }^{7}$ This view is called Ricardo-Bar's theorem. In practice, the Ricardian equivalence does not exist. Larger deficits impact on economic activity by increasing aggregate demand and GDP in the short term. In the long run, the accumulation of debt reduces the accumulation of capital that reduces GDP.

${ }^{8}$ Robert Barro, Charles Redlick, ,Macroeconomic Effects from Government Purchases and Taxes“, NBER Working Paper 15369/2009; Robert E. Lukas, Nancy L. Stokey, "Optimal Fiscal and Monetary Policy in Economy without Capital”, Journal of Monetary Economics 12/1983, 55-93.

9 Alberto Alesina, Roberto Perotti, „The Political Economy of Budget Deficits”, NBER Working Paper 4637/1994, http://www.nber.org/papers/w4637.pdf, 22 January, 2017; Alberto Alesina, Roberto Perotti, ”Budget Deficits and Budget Institutions”, NBER Working Paper, 8021/1999, http://www.nber.org/chapters/c8021, 05 February, 2012.

${ }^{10}$ David Romer, Advanced Macroeconomics, McGraw-Hill, New York 2012, 602-605. 
national income. Public debt then receives all the features of "additional" national accumulation. At the stage when there is the maturity date for interest, there is an outflow of national income, which is seen as a loss for the national economy (export growth, limiting domestic consumption, boosting foreign exchange reserves). ${ }^{11}$ The optimal solution is that the government, if possible, creates a tax policy without taxing the capital. Taxes on capital and income taxes have distortionary effect on the free choice of the individual, because they reduce the overall attractiveness of work. However, the taxation of capital disturbs the intertemporal choice of individuals.

Third, the model of tax smoothing regards public spending as the exogenic variable. The reduction in public spending increases household resources, and thus increases their private consumption. This proves that taxes are distorting and that there is a deviation from the Ricardian equivalence. In the case of endogenous public spending, tax cuts increased expectations of future tax liabilities for an amount less than today's reduction so that private consumption is growing. This role of the expectations indicates the possibility that there are situations in which an increase in taxes or cuts in public spending increases the aggregate demand for goods and services. As an illustration, it is assumed that for some reason a small increase in taxes means that there will be a lot of cuts in public spending in the future and, in this context, large tax benefits. Households will react to tax increases by the overvaluation of their existential resources, and as a result, they can increase their personal consumption. Similarly, a small reduction in current public spending may signal future large reductions, and therefore cause an increase in personal spending by the amount larger than the amount of the reduced public spending.

In addition to numerous advantages in explaining economic effects of tax cuts, Barro's hypothesis is disputed by some unrealistic assumptions. First of all, the connection between the current deficit and future taxes is not reasonably foreseeable. People are bound by their decisions for the short term and are not realistic in terms of long term, and intergenerational relationship is not as prominent as the model assumes.

\section{POLITICAL AND INSTITUTIONAL DETERMINANTS OF FISCAL DEFICIT}

The four different models are used for the analysis of the political and institutional determinants of fiscal deficit and public $\operatorname{debt}^{12}$ : (1) the model of opportunistic politicians and naive voters (model of fiscal illusion); (2) the model of intergenerational distribution; (3) the model of the spatial distribution of interest; and (4) the model of budget institutions and procedures as a determinant of the fiscal deficit.

${ }^{11}$ Jadranka Đurović-Todorović, Marina Đorđević, Javne finansije, Ekonomski fakultet, Niš 2010, 349-340.

${ }^{12}$ Alberto Alesina, Roberto Perotti,'Budget Deficits and Budget Institutions", NBER Working Paper 8021/1999, http://www.nber.org/chapters/c8021, 05 February, 2012. 


\subsection{Model of fiscal illusion}

Theories of fiscal choice based on political reasons indicate manipulation of public spending because it is used as a tool by politicians in order to win the next elections. Naive voters evaluate public spending and assess their costs in terms of tax burden, especially if these costs were deferred. In other words, voters support parties that use deficit to finance high public expenditure, while they do not support the parties with strict fiscal rules. In this way, voters indirectly encourage fiscal irresponsibility. In addition, deficit financing of public spending generate asymmetric stabilization, where politicians are willing to increase the fiscal deficit to fight the recession, but are not ready to achieve a surplus in times of economic expansion.

One part of the relevant research refers to the use of opportunistic deficit in the pre-election period. This study investigates the behavior of fiscal deficits and public expenditure before the political elections. The main conclusions are not supported by the unconditional pre-election fiscal expansion. Persson and Tabel$l i n i^{13}$ do not notice a pre-election change in public spending or surplus in a large sample of developed and less developed countries. However, pre-election increase in public spending and the fiscal deficit were observed for certain groups of countries. Shi and Svensson in their research prove election deterioration of fiscal balances and an increase in public spending in developing countries. They noted that the negative effect of the election period on the deficit is lower among better informed voters. ${ }^{14}$ Brender and Drazen suggest that these findings reflect the experience of transition countries in the first few years after the transition to a democratic regime.

The empirical evidence confirms the basic predictions of the model based on the promised manipulation of fiscal policy. First, the degree of transparency of the budget can be measured through the accumulation of the debt. Second, the increase in the fiscal deficit and public spending because of the elections is characteristic of the countries where voters are less successful in monitoring fiscal results. ${ }^{15}$

The empirical research explained why perfectly rational voters would support the opportunists in the current poll. The structure and level of public spending depends on how competent official politicians and voters have only imperfect information about the level of expertise of the politicians. In that way voters form

13 Torsten Persson, GuidoTabellini, "The size and scope of government: Comparative politics with rational politicians", European Economic Review 43/1999, 699-735.

${ }^{14} \mathrm{Shi}$ and Svensson prove that the high level of corruption of politicians is causing sharp increases in deficits in election years. See more: Min Shi, Jakob Svensson, "Political budget cycles: Do they differ across countries and why“"? Journal of Public Economics, Vol. 90/2006, Issues 8-9, 1367-1389.

${ }^{15}$ Marcela Eslava, "The Political Economy of Fiscal Deficits: A Survey", Journal of Economic Surveys, Vol.25/2011, No.4, 645-673. 
an opionion about the competence of politicians according to their previous fiscal choices. It can be concluded that a competent politician is the one who in the previous term provided the programme of more public spending. This encourages politicians to increase the deficit in order to finance higher public spending. An additional argument for rational manipulation of fiscal deficit is that voters know the details of the budget. If they are familiar with the cost of all projects undertaken by the government, they will perfectly know what competences the current officials have. Rogoff ${ }^{16}$ assumed that voters are familiar with a part of the expenditures of the government ("visible" expenditures). Shi and Svenson ${ }^{17}$ show that the fiscal deficits can arise if voters know all public spending programmes, but they are not informed about fiscal balance. In any of these scenarios, the accumulation of debt, which results from the opportunistic behaviour of politicians, show how the budget was transparent: less transparency leads to higher opportunistic deficits. ${ }^{18}$ Alt and Lase $^{19}$ constructed an index of fiscal transparency for every country. They study whether the index of transparency is connected with the fiscal discipline in these countries. Their findings suggest that a greater degree of budget transparency leads to a reduction in the deficit and public debt levels.

\subsection{Model of intergenerational distribution}

By increasing public debt the government shifts the tax burden from the old to the young or from the current to future generations. Intertemporal nature of fiscal decisions creates a link between generations. According to the Ricardian equivalence proposition, the choice of methods for financing public expenditure (taxation or borrowing) is irrelevant, because the distribution of the tax burden between generations does not affect the size of the debt (changes in public debt compensate for changes in private saving).

In models where the Ricardian equality is not true, the public debt can generate intergenerational redistribution, if the present generation lives on the debt at the expense of future generations. Thus, in principle, a selfish generation can vote for policies that shift the burden of taxation in the future.

${ }^{16}$ Kenneth Rogoff, "Equilibrium Political Budget Cycles”, American Economic Rewiev, Vol. 80/1990, No.1, 21-36.

${ }^{17}$ Min Shi, Jakob Svensson, "Political budget cycles: Do they differ across countries and why“? Journal of Public Economics, Vol. 90/2006, Issues 8-9, 1367-1389.

${ }^{18}$ Although models of Rogoff, Shi and Svensson explained opportunistic deficits only during election time, this class of models can explain the accumulation of opportunistic debt after the election period. In the model of Alt and Lassen, for example, the manipulation is not dependent on the electoral cycle. Whether fiscal manipulation is present all the time or not, the choice depends on the specific context, especially on how far back voter view when deciding who to vote for. See more: James Alt, David Lassen,'Political and Judicial Checks on Corruption: Evidence from American State Governments“, Economics \& Politics, Vol.20/2008, No1, 33-61.

${ }^{19}$ Ibid. 
Efficiency is not the only criterion used to estimate the distribution of the burden between generations. Many people claim that the results should be assessed from the point of fairness. There are two key principles of capital used in the evaluation of the transfer of the tax burden on future generations: the principle of utility and the principle of capacity to pay.

The principle of utility is quite clear, and its implications are as follows: increasing public debt is unjustified for future generations if they do not get the benefit of current public spending comparable to the increased tax burden to bear. However, if government bonds are used to finance public investment rather than current spending, the conclusion is quite different. If future generations inherit a larger stock of public capital (e.g. the network of national roads) which brings them benefits, it is reasonable that they should bear part of the tax burden.

When assessing the fairness of fiscal policy, then the principle of capacity to pay is used. In accordance with the principle of vertical equity, the government should distribute the tax burden according to ability to pay. If future generations will have a greater ability to pay than the current generation, it is fair to shift a greater burden on them, regardless of whether they would benefit from public spending. Vertical equity explains why some people believe that public debt is not a problem until it grows faster than the economy. Higher economic growth means that the economy has more affluent citizens with greater ability to pay the taxes required to service the growing public debt. Switching the tax burden from the present generation, which is richer and more numerous, to the future generations is not fair. In the evaluation of economic policy, it is important to understand both efficiency and distributive consequences of alternatives. Improving efficiency is often strongly opposed by special interest groups that would suffer losses if improvements are adopted. These groups are interested in protecting their income from political actions at the cost of reducing production and prosperity of the economy as a whole. The current policies and institutions reflect a conflict between a group of individuals who want to protect and increase revenues from their actions and individuals who advocate the effective use of resources for the benefit of the whole community. ${ }^{20}$

Cukierman and Meltzer ${ }^{21}$ propose an interesting political model of intergenerational redistribution. Their key idea can be summarized briefly as follows. It is assumed that in the current generation, there are "rich" and "poor" parents. The "rich" are individuals who plan to leave some capital for their descendants. They are indifferent to the politics of public debt, as it can compensate any change in current taxes and deficits by adjusting their savings. "The poor" are individuals

${ }^{20}$ David Hyman, Public Finance A Contemporary Application of Theory to Policy, SouthWestern Cengage Learning 2011, 56-58.

${ }^{21}$ Alex Cukierman, Allan Meltzer, "A Political Theory of Government Debt and Deficits in a Neo-Ricardian Framework”, American Economic Review, Vol. 79/1989, Issue 4, 713-732. 
who want to leave a negative budget to future generations. Since they cannot borrow it from our descendants, "the poor" want to increase the fiscal deficit. As a result, they indirectly borrow from future generations. Thus, one group ("rich") is indifferent to any policy of debt, while the second group ("poor") favours public debt. Due to the fact that the social choice comes from the rule of the majority, it means that the government will choose the option of borrowing. Why should future generations (today's generation's children) be given public debt? Alesina et $a l^{22}$ responding to the latter criticism, argue that the intergenerational redistribution is correlated with intragenerational redistribution. The selection involves redistribution from the holder of the debt to the taxpayer, that is, from the "old" to "young" and from "rich" (who have taken the debt) to the "poor" (who will return).

\subsection{Model of the spatial distribution of interest}

The economic analysis of law studied how legislation leads to inefficient fiscal decisions. ${ }^{23}$ Time lag of the legislative power is the direct cause of the current unsatisfactory results in the field of harmonizing national budgetary policies, public debt management policy and unsatisfactory implementation of legal restrictions on the fiscal deficit and public debt in national and European monetary law. ${ }^{24}$

Proponents of the spatial separation of interests assess the benefits of public projects in their districts in relation to financing costs. In practice it is possible that jurisdiction, which means responsibility for a project of public interest, belongs to one level of government, to be funded by another, and delivered by a third level of authority. This is a territorial division of powers, i.e. the allocation of fiscal sovereignty on the public expenditure.

The spatial distribution of expenditures for public spending is also called fiscal decentralization and is the basis for fiscal federalism. The theory does not emphasize any public expenditure allocated to the sub-central government, but it is left to the government to determine them in accordance with the size of their sub-units, constitution, political relations, the development of individual branches and regions, and a number of other factors. There is often a compromise between the political and economic components of federalism. Thus, the public asset that is from the standpoint of economic criteria a national public asset will be transferred to the local authority. There can be asymmetric decentralization where, in

${ }^{22}$ Alberto Alesina, Dorian Carloni, Giampaolo Lecce, „The Electoral Consequences of Large Fiscal Adjustments“, NBER Working Paper 17655/2011, http://www.nber.org/papers/w17655, 19 June, 2012.

${ }^{23}$ Bary R.Weingast, Keneth A. Shepsle Christopher Johnsen, "The Political Economy of Benefits and Costs: A Neoclassical Approach to Distributive Politics", Journal of Political Economy, Vol.89/1981, no.4, 642-664.

${ }^{24}$ Marko Dimitrijević, „Uloga evropskog revizornog suda u očuvanju fiskalnog okvira evrozone“, Zbornik radova Pravnog fakulteta u Novom Sadu 2016/3, 911. 
order to calm down political tensions, certain responsibilites are assigned to certain regions in the country. This is a case in Spain where Catalonia and the Basque have a wider authority than other regions, or in the Federation of Bosnia and Herzegovina, where local communities whose majority population is nationally different from the majority population of the canton have bigger authority ${ }^{25}$.

Fiscal imbalance is a situation where lower levels of authority do not have sufficient resources to cover the allocated expenditures with their own revenues. Funds allocated to certain units to adjust fiscal imbalances are called intra-budget transfers. When determining transfers, a number of factors that affect the scope and type of transfers and the method of transfer should be considered ${ }^{26}$ Also, depending on the characteristics, it is necessary to define the type of transfers that can be conditional and non-conditional, proportional and disproportionate, exclusive and shared ${ }^{27}$.

Transfer and subsidies programmes may be selected on a territorial basis. These are cases where the redistribution of income and geographical redistribution have become very interconnected. For example, disability pensions were used as a transfer system from northern to southern Italy. In Serbia, subsidies represent the price paid by the state to investors for the bad business environment, and thus indirectly do unequal spatial distribution of income.

The problems of spatial distribution of expenditures (fiscal decentralization) make up only one part of the current fiscal problems of modern economies. It is difficult to imagine that significant fiscal adjustment programmes are sustainable without affecting transfers and social welfare programmes. The models of spatial distribution of interest are not adequate to explain the repercussions of the mentioned impact. However, the models can explain that the geographical distribution of costs, benefits, and decision-making powers can make a significant difference in the central government budget. For example, let us suppose that public spending decisions are made locally, and are funded by transfers from the central government. In this case, local governments do not consider the effects of spending decisions on the central budget. However, local government initiatives on spending will differ if they are responsible for both taxation decisions and spending decisions, which is the topic of fiscal responsibility of local authorities ${ }^{28}$.

The arrangements of fiscal federalism and fiscal decentralization can be well-designed and well implemented, but it is possible that public goods are not

${ }^{25}$ Ljiljana Jović, Fiskalni federalizam, Bijeljina 2012, 224.

${ }^{26}$ Snežana Stojanović, Fiskalni federalizam, Institut za uporedno pravo-Centar za antiratnu akciju, Beograd 2005, 130; Ljiljana Jović, Fiskalni federalizam, Bijeljina 2012, 190.

${ }^{27}$ Council of Europe, A handbook on finance at Local and Regional Level, http://www.mju. gov.si/fleadmin/mju.gov.si/pageuploads/JAVNA_UPRAVA/svlsrp.gov.si/pageuploads/loksam-2015/splosno-ls-ls/pokrajine/HandbookFinance.pdf, 18 June, 2017.

${ }^{28}$ Alberto Alesina, Roberto Perotti, „The Political Economy of Budget Deficits”, NBER Working Paper 4637/1994, http://www.nber.org/papers/w4637.pdf, 22 January, 2017. 
produced in an efficient manner and in that way there is unnecessary waste of resources. Fiscal decentralization can provide different budgetary outcomes, depending on the characteristics of domestic fiscal frameworks, including the elements such as fiscal rules applied by regional and local authorities or their alternative sources of funding.

\subsection{Models focused on the importance of budget institutions}

The economic analysis of law specifically explores the importance of institutional reforms in the implementation of fiscal policy. If the fiscal deficit is caused by a primary factor, namely political-institutional variables, in order to improve fiscal policy there should be intervention at the institutional level. In this case, institutional reforms are related to the method of budgeting and changes in the electoral laws.

Budgeting is a process that consists of a series of related and interdependent phases: budget formulation, adoption, execution and supervision. The government submit the proposal of the budget to the legislative body to discuss and approve it. The budget adoption process may be quite complicated, especially with coalition governments. The most favoured reform of the budget process refers to the adoption of the Law on the balanced budget. This law would limit the discretionary polity of any government - the possibility for tax reduction and increase in public spending would be restricted. Until the appearance of J.M. Keynes, the policy of the balanced budget was absolutely inviolable. Tax smoothing theory considered the policy of the balanced budget optimal. However, models of budgetary institutions claim that this theory is not entirely accurate to describe the actual fiscal policy. As the economic cycles last more than a year, the law on the balanced budget delays the macroeconomic stabilization. The model of delayed stabilization is essentially a model of coalition conflicts ${ }^{29}$. The basic idea of the model is that every coalition party decided to delay the reforms and thus try to get a better offer. By delaying the reforms, the coalition party expects an increase in personal interests and then the total economic situation would deteriorate. The final result can be delayed stabilization although there are reforms from which everyone can benefit ${ }^{30}$.

${ }^{29}$ Alberto Alesina, Allan Drazen, „Why Are Stabilization Delayed“, American Economic Review 81/1991, 1170-1188; Chang-Tai Hsieh, „Bargainning over Reform“, European Economic Review 44/2000, 1659-1676.

${ }^{30}$ Hyperinflations are the clearest example. Given the enormous disruptions hyperinflations create, there is little doubt that there are policies that would make most people considerably better off. Yet reform is often delayed as interest groups struggle over how to divide the burden of the reform. In the hyperinflations after World War I, the struggles were largely over whether higher taxes should be levied on capital or labor. In modern hyperinflations, the struggles are typically over whether the budget deficit will be closed by tax increases or by reduction government spending. See: David Romer, Advanced Macroeconomics, McGraw-Hill, New York 2012, 617-618. 
The second stage in which the "coalition conflicts" may take place and jeopardize fiscal responsibility is in the regulatory approval of the budget. There are procedures which limit the deficit. They are related to (i) limiting the acceptance of changes and (ii) the imposition of the procedure to first vote on on the size of the total consumption, and then to discuss its structure. In the context of the budget procedure, it is very important to control the implementation of the formed and adopted budget. For example, one of the key reasons that contributed to the recovery of public finances of Serbia at the beginning of the 20th century lies in the parliamentary oversight of the budget items of income and expense. ${ }^{31}$

When the fiscal deficit occurs, it is partly financed from the accumulation of the external debt and partly from a form of taxation. Stabilization means policy change which will stabilize the debt to GDP ration and taxation through less distortive "regular" forms of taxation. Let us assume that two groups must decide how to share the fiscal burden of stabilization. The longer they delay it, the larger are the costs from two reasons. First, during pre-stabilization fiscal distorsions the public debt will accumulate so higher taxes will be needed to cover it after stabilization. Second, for both groups is better to reach an agreement about how to share the fiscal burden of the stabilization. However, these cases of delaying occur from two reasons: (i) proposed stabilization is "unfair" - one group will take larger fiscal burden, and (ii) both groups are not informed about alternatives, i.e. each group does not know the price of delaying for the other group. Hillman points out the incentive for keeping the reputation of the formed coalition although inefficiency of the reaction of the coalition government grows with the number of coalition partners ${ }^{32}$.

This research links the accumulation of the public debt with the fragmentation of the government and observes it as political cohesion. Less cohesion means more difficulties to reach an agreement on the fair distribution of the costs of fiscal adaptation. Therefore, it delays the growth of the debt. The models of coalition conflicts explain why the countries prolong fiscal adaptation. However, these models do not explain the cause of the original shock that deteriorates the fiscal balance because different institutions give different answers to the mutual shock. Weak coalition governments usually have delayed fiscal adaptations and have accumulated debts. Rubini and Sachs constructed the political indicator that assumes the increase in the public debt with the increase in government fragmentation ${ }^{33}$. Therefore, a larger number of political parties generate a higher level of public debt.

\footnotetext{
${ }^{31}$ Goran Milošević, Mirko Kulić, "Razvoj poreskog sistema Srbije do drugog svetskog rata", Zbornik radova Pravnog fakulteta u Novom Sadu 2016/ 1, 55-69.

${ }^{32}$ Arye Hillman, Public Finance and Public Policy - Responsibilities and Limitations of Government, Cambridge University Press, Cambridge 2009, 433.

${ }^{33}$ Nouriel Roubini, Jeffrey Sachs, „Political and Economic Determinants of Budget Deficits in the Industial Democracies“, European Economic Review 33/1989, 903-933.
} 
Grili et al. show the fiscal deficit in the correlation with the survival of the government. ${ }^{34}$ Their conclusion is that governments that last longer have smaller deficit. These findings are in accordance with the previous one because coalition governments usually last shorter than majority governments. In addition, there are almost no institutional supervisions that, according to Henisz ${ }^{35}$, may improve the economic result. It was confirmed by Leachman et al. ${ }^{36}$ that the fiscal performance is weaker when the supervision of fiscal budgetary institutions is weaker.

Some studies analyze the influence of budgetary institutions on the debt accumulation. Group of authors ${ }^{37}$ construct an index of budgetary institutions, which summarizes several budget categories: budgetary procedures, budgetary policies and budget control, the comprehensiveness of the budget and its transparency. If the index of budgetary institutions is higher, the country is more fiscally responsible. The results show that the indices of budgetary institutions are significant variables that could explain the differences in the level of public debt among countries. For example, these aggregate indices can hide many institutional differences. For example, France and Germany have high indices of budgetary institutions but different institutional solutions. France has the unique electoral system. The government is elected through parliamentary majority and is responsible to the parliament although the real responsibility is to the President who is not responsible to the parliament. The fact that the President got votes from more than half of the voters this person is given tremendous power. This leads to the quality of budgetary system and institutions in France. In Germany, the electoral system is the combination of the majority and proportional system ("personalized proportional system") which is compatible with fiscal responsibility. However, the transparency of the budget and consistence in its implementation generate the high index of budgetary institutions in Germany. The United States have a number of different solutions related to their budget. In addition to the various procedures for the formation of the budget, some states have "hard" rules of budgetary balance; others have "loose" rules of budgetary balance, whereas a few states even have no rules. In other words, there may be a lot of institutional rules even in the

\footnotetext{
${ }^{34}$ Vittorio Grilli, Donato Masciandaro, Guido Tabellini, „Political and Monetary Institutions and Public Financial Policies in ghe Industrial Countries“, Economic Policy 13/1991, 341-392.

${ }^{35}$ Witold Henisz, "Political Institutions and Policy Volatility", Economics and Politics, Vol. 16/2004, Issue 1, 1-27.

${ }^{36}$ Lori Leachman, Guillermo Rosas, Peter Lange, Alan Bester, "The political economy of budget deficits", Economics \& Politics, Vol.19/2007, Issue 3, 369-420.

${ }^{37}$ Era Dabla-Norris, Richard Allen, Luis-Felipe Zanna, Tej Prakash, Eteri Kvintradze, Victor Lledo, Irene, Yackovlev, Sophia Gollwitzer, "Budget Institutions and Fiscal Performance in Low-Income Countries", International Monetary Found Working Paper 80/2010,

https://papers.ssrn.com/sol3/papers.cfm?abstract_id=1583338\&rec=1\&srcabs=1365111\&alg $=7 \&$ pos $=3$, 9 September, 2017.
} 
country with the unique aggregate index. ${ }^{38}$ There are also differences in the methodology of budgeting. It is often assumed that the top-down budget process results in less total budget than in the case of the bottom-up budget process. More recent empirical studies dispute this theoretical assumption. ${ }^{39}$

The nature of coalition and the government structure depend on the electoral system. The advantage of the proportional electoral system is that it secures the internal distribution of political authority and balance of political interests, and the disadvantage is that there are less powerful parties and this leads to coalition governments. The advantage of the majority system is that it positions political responsibility because it leads to the forming of the government of majority parties. The disadvantage is the possibility of dominance of local interests at the central level and populism, which causes the increase in deficit and public debt. ${ }^{40}$ How to make a choice between these trade-offs?

Economic and legal theory partly gives answers to this question. The advantages and disadvantages of the majority and proportional systems are not mutually comparable. In addition, it depends on the environment whether the majority system will show its advantages or disadvantages. The problem of bad politicians is not solved only by moving from one electoral system to another. The introduction of the personalized proportional election system forces the political parties to reform and offer the best (and most honest) individuals to the citizens. In addition, the reform of laws relating to parties, corruption and the rule of law is needed.

\section{CONCLUSION}

High levels of fiscal deficit and public debt are the main economic problem in both developed countries and developing countries. In order to treat the consequences of these problems, the causes that generate them must first be removed. At the same time, economic policy implemented through the tax reduction is quite clear: fixal deficit and suficit are optimally used to minimize the adverse effects of taxation, with certain fluctuation of public expenditure. However, if the fiscal deficit is caused by the primary factor (political-institutional variables) in order

\footnotetext{
${ }^{38}$ James Poterba, Jürgen Von Hagen, (Eds.), Fiscal Institutions and Fiscal Performance, University of Chicago Press, Chicago 1992, 81-102.

${ }^{39}$ Karl-Martin Ehrahrt, Row Gardner, Jürgen Von Hagen, Claudia Keser, "Budget-processes: Theory and experimental evidence", Games and Economic Behavior, Vol. 59/2007, Issue 2, 279-295; European Commision, "Fiscal relations across government levels in times of crisis - making compatible fiscal decentralisation and budgetary discipline", Economic Paper 501/2012, http:// ec.europa.eu/economy_finance/publications/economic_paper/2013/pdf/ecp501_en.pdf, 20 September 2013.

${ }^{40}$ Torsten Persson, GuidoTabellini, “The size and scope of government: Comparative politics with rational politicians", European Economic Review 43/1999, 699-735.
} 
to improve the implementation of fiscal policy, there must be an intervention at the institutional level. One can think of two types of institutional reforms, such as the method of forming the budget and changes in the electoral laws.

An analysis of the determinants of the fiscal deficit has confirmed the given hypotheses. The key message of this study is that budgetary institutions affect fiscal policy. Institutional differences certainly contribute to a high fiscal deficit in some countries, which are homogeneous groups in the economic sense. The impact of economic shocks on different budget institutions may have the consequence that they will insufficiently implement fiscal responsibility, which will have a particularly negative impact on the success of fiscal consolidation. Fiscal responsibility and the quality of budgetary institutions differ in the context of the circumstances in which the advantages and disadvantages of different electoral systems are prominent. For this reason, the solution to the problem is not visible in transferring from one electoral system to another. The solution is a bit more complicated, and it means the adaptation of the laws on parties, corruption and the rule of law. 
Др Марија Р. Вуковић, ӣрофесор ст̄руковних стиудија Висока йословна шикола стируковних стиудија Нови Сад vlahmari@uns.ac.rs

\section{Економске и политичко-институционалне детерминанте фискалног дефицита}

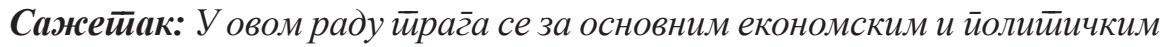

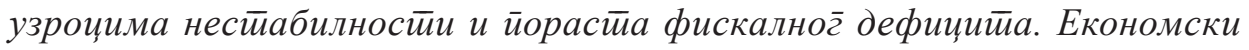

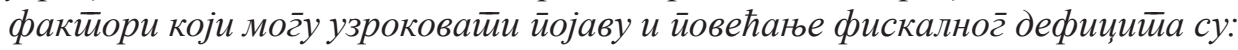

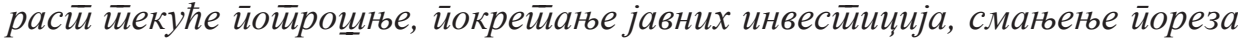

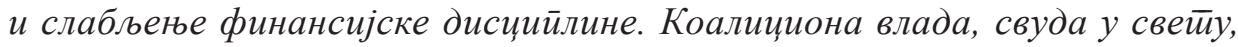
иредстиавља йримарни фактиор који узрокује формирање и йорасти фискалног̄ дефициай. Циљ рада је йоказаиии да су йолитички несйабилне земље, са слабим буиетиским инстиитицијама, осейливе на фискалне щокове који, доводе до йорасйа фискалног̄ дефииийа.

Кључне речи: смањење иореза; фискална илузија; међугеенерацијска

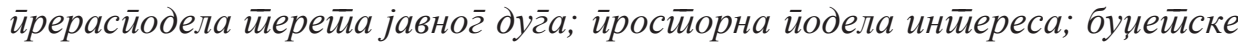
инстиийуције.

Датум пријема рада: 24.04.2017. 